Singapore National Eye Centre, 11 Third Hospital Avenue, Singapore 168751 Z Alsagoff

D T H Tan

S-P Chee

Correspondence to: Dr S-P Chee sneccsp@pacific.net.sg

Accepted 26 April 2000

\title{
Necrotising scleritis after bare sclera excision of pterygium
}

\author{
Zainah Alsagoff, Donald T H Tan, S-P Chee
}

\begin{abstract}
Aim-To report cases of scleral necrosis after simple pterygium excision in which adjunctive treatment was not used.

Methods-We reviewed four patients who presented with scleral melt after pterygium excision without the use of adjunctive treatment in the form of $\beta$ irradiation, mitomycin $\mathrm{C}$, or thiotepa. Each patient was thoroughly investigated to exclude underlying disease.

Results-Certain similarities were found between our patients with pterygium melt and cases of surgically induced necrotising scleritis including the location of melt, associated inflammation, and its response to steroid treatment in the latent period before they presented.

Conclusion-Bare sclera pterygium excision can cause surgically induced necrotising scleritis years after the surgery. (Br f Ophthalmol 2000;84:1050-1052)
\end{abstract}

Surgically induced necrotising scleritis (SINS) has been reported to occur after cataract extraction, trabeculectomy, squint surgery, and surgery for retinal detachment. ${ }^{12}$ It typically presents as a focal area of intense scleral inflammation occurring adjacent to the site of previous scleral or limbal incision. ${ }^{1}{ }^{2}$

Scleral melting and necrosis is also a well reported complication following pterygium surgery in relation to the use of adjunctive $\beta$ irradiation $^{2-4}$ or treatment with mitomycin $C^{5}{ }^{5}$ This has been ascribed to the prolonged inhibition of wound healing which can occur with these antiproliferative agents.

Before 1994 excision of bare sclera pterygium was widely practised because it was believed to be safe and simple until a randomised prospective study showed that the recurrence rate was unacceptable at $62 \% .{ }^{6}$ We describe four cases of necrotising scleritis following simple pterygium excision in which adjunctive treatment was not used. Possible causative factors in scleral melting after simple pterygium excision are discussed, and the relation of these cases to SINS is compared and evaluated. We believe that scleral necrosis following pterygium excision using the bare sclera technique has not previously been described in the literature.

\section{Methods}

We retrospectively analysed four patients who presented at the Singapore National Eye Centre from 1990 to 1996 with scleral melt which developed after pterygium excision. They had undergone surgery without any adjunctive treatment in the form of $\beta$ irradiation, mitomycin C, or thiotepa. This was confirmed by contacting their previous surgeons.

The clinical records of these patients were studied and data were extracted with particular reference to presenting symptoms, interval between surgery and presentation, clinical features, investigations performed to exclude associated connective tissue diseases, and treatment administered.

Haematological investigations included blood counts, erythrocyte sedimentation rate, FTA-abs (fluorescent treponemal antibody absorption), VDRL (Venereal Disease Research Laboratory), urea and electrolytes, liver function test, urine analysis, anti-neutrophil cytoplasmic antibody (ANCA), CH50 (total haemolytic complement), $\mathrm{C}$ reactive protein (CRP), immunoglobulins (Ig) $\mathrm{G}, \mathrm{A}$ and $\mathrm{M}$, uric acid, rheumatoid factor, antinuclear antibody (ANA), and anti-double stranded DNA. Chest radiography and the Mantoux test for tuberculosis were also performed. A swab culture was taken to exclude microbial infections.

\section{Results}

The patients were found to have certain similarities with surgically induced necrotising scleritis. All had undergone bare sclera pterygium surgery and no adjunctive treatment was given. The period between surgery and melt was variable, ranging from 18 months to 40 years. The area of scleral necrosis was located at or adjacent to the previous surgical site. Associated inflammation was present in two of the four cases. The scleral necrosis responded to immunosuppressive treatment similar to that prescribed for SINS. Details of the four cases are given in Table 1.

\section{Discussion}

Scleral melting occurring after pterygium surgery with adjunctive treatment has been well reported. Adjunctive treatments implicated as causative factors include the use of $\beta$ irradiation, ${ }^{2-4}$ thiotepa, ${ }^{4}$ and mitomycin $\mathrm{C}^{5}$, all of which are used to reduce the recurrence of pterygium after excision. $\beta$ Irradiation is 
Table 1 Report of four cases with necrotising scleritis after bare sclera excision of pterygium

\begin{tabular}{|c|c|c|c|c|c|c|}
\hline Case no & Age/sex/race & Presenting symptoms & Clinical findings & Investigations & Treatment & Outcome \\
\hline 1 & $69 / \mathrm{F} / \mathrm{Ch}$ & $\begin{array}{l}\text { RE pain and red for } 6 \\
\text { months } \\
\text { RE nasal pterygium } \\
\text { excision } 18 \text { months ago }\end{array}$ & $\begin{array}{l}\text { RE sclera melt } 10 \times 3.5 \\
\text { mm inferonasally with } \\
\text { sequestrum (Fig 1) } \\
\text { Inflamed nodule } \\
\text { inferotemporally } \\
\text { Anterior chamber cells } \\
\text { and flare } \\
\text { Exudates in inferonasal } \\
\text { retina away from } \\
\text { posterior pole }\end{array}$ & $\begin{array}{l}\text { CH50: } 51 \mathrm{U} / \mathrm{ml}(13-37 \\
\mathrm{U} / \mathrm{ml}) \\
\mathrm{IgG:} 15.9 \mathrm{~g} / 1 \mathrm{l}(7.3-15.4 \\
\mathrm{g} / \mathrm{l}) \\
\text { ESR: } 60 \mathrm{~mm} / \mathrm{h}(3-15 \\
\mathrm{mm} / \mathrm{h}) \text { Positive ANA }\end{array}$ & $\begin{array}{l}\text { Oral indomethacin } 25 \mathrm{mg} \text { three } \\
\text { times daily, topical } \\
\text { dexamethazone } 0.1 \% \text { two hourly, } \\
\text { topical homatropine } 2 \% \text { twice } \\
\text { daily } \\
\text { Scleral necrosis progressed. Large } \\
\text { tectonic lamellar keratoplasty } \\
\text { (using corneal tissue) extending } \\
\text { beyond medial rectus insertion } \\
\text { done with preoperative } \\
\text { intravenous methylprednisolone } \\
1 \text { g given } \\
\text { Postoperative oral prednisolone } \\
60 \text { mg daily for } 2 \text { weeks } \\
\text { Inferotemporal scleral nodule } \\
\text { melted when steroids stopped. } \\
\text { Oral prednisolone } 40 \text { mg daily } \\
\text { recommenced and tapered over } 6 \\
\text { weeks }\end{array}$ & $\begin{array}{l}\text { No recurrence after } 2 \\
\text { years } \\
\text { Vision at } 6 / 12\end{array}$ \\
\hline 2 & $61 / \mathrm{M} / \mathrm{Ch}$ & $\begin{array}{l}\text { LE blurred vision LE } \\
\text { pterygium excision } 20 \\
\text { and } 40 \text { years ago }\end{array}$ & $\begin{array}{l}\text { LE area of scleral melt } \\
\text { nasally with } \\
\text { inflammation covered by } \\
\text { conjunctival epithelium } \\
\text { Cornea shows signs of } \\
\text { limbal stem cell } \\
\text { deficiency }\end{array}$ & $\begin{array}{l}\text { IgA: } 6.08 \mathrm{~g} / 1(0.7-3.76 \\
\mathrm{g} / \mathrm{l}) \\
\text { Active tuberculosis }\end{array}$ & $\begin{array}{l}\text { Limbal autograft transplant done } \\
\text { for cornea problem only }\end{array}$ & $\begin{array}{l}\text { Scleral melt remained } \\
\text { stable without } \\
\text { treatment after } 3.5 \\
\text { years } \\
\text { Vision at } 6 / 12\end{array}$ \\
\hline 3 & 79/M/Ch & $\begin{array}{l}\text { LE blurred vision RE } \\
\text { pterygium excision } 20 \\
\text { years ago }\end{array}$ & $\begin{array}{l}\mathrm{RE} \text { nasal scleral melt } \\
\text { with overlying staining } \\
\text { plaque }\end{array}$ & $\begin{array}{l}\text { Gout in the past } \\
\text { Uric acid } 644 \mu \mathrm{mol} / 1 \\
(232-494 \mu \mathrm{mol} / \mathrm{l}) \text { Positive } \\
\text { ANA }\end{array}$ & $\begin{array}{l}\text { Lamellar patch graft done with } \\
\text { removal of plaque }\end{array}$ & $\begin{array}{l}\text { No recurrence for } 2.5 \\
\text { years }\end{array}$ \\
\hline 4 & $74 / \mathrm{F} / \mathrm{Ch}$ & $\begin{array}{l}\text { LE red and pain for } 3 \\
\text { months } \\
\text { LE nasal pterygium } \\
\text { excision } 4.5 \text { years ago } \\
\text { LE cataract surgery } 2.5 \\
\text { years ago }\end{array}$ & $\begin{array}{l}\text { Scleral melt with } \\
\text { inflammation } \\
\text { superonasally with intact } \\
\text { overlying conjunctiva } \\
\text { (Fig 2) }\end{array}$ & $\begin{array}{l}\text { CRP: } 14.3 \mathrm{mg} / \mathrm{l}(1-10 \\
\mathrm{mg} / \mathrm{l})\end{array}$ & $\begin{array}{l}\text { Tapering oral prednisolone } 80 \mathrm{mg} \\
\text { daily, maintaining at } 10 \mathrm{mg} \text { daily } \\
\text { for } 2.5 \text { years } \\
\text { Reactivates when prednisolone } \\
\text { lower than } 10 \mathrm{mg} \text { daily }\end{array}$ & $\begin{array}{l}\text { Scleral melt stable with } \\
\text { prednisolone at } \\
\text { maintenance dose for } \\
2.5 \text { years } \\
\text { Vision at } 6 / 18\end{array}$ \\
\hline
\end{tabular}

$\overline{\mathrm{CH} 50}=$ total haemolytic complement; ESR = erythrocyte sedimentation rate; IgG, IgA = immunoglobulin G and A; ANA = antinuclear antibody; CRP = C reactive protein.

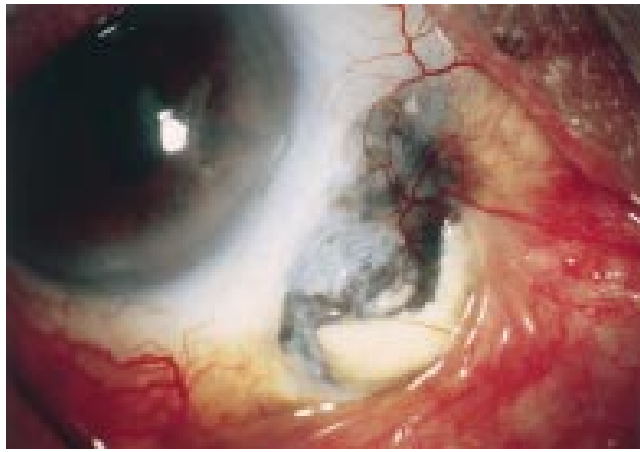

Figure 1 Area of scleral melt inferonasally in the right eye with uvea exposed and an adjacent sequestrum. There is a loose eyelash in the picture.

believed to cause obliterative endarteritis ${ }^{2}$ and thiotepa and mitomycin are thought to cause inhibition of mitosis of capillary endothelial cells. $^{2}$

In the absence of antiproliferative agents in the four patients described in this report, alternative factors that might have caused scleral melting or necrosis have to be considered. The site of scleral melting occurred at the site of previous pterygium excision. As scleral melting occurred after surgical excision in all cases, this was strongly suggestive of a relation with the disease entity of SINS. Certainly, one might argue that these were cases of idiopathic necrotising anterior scleritis with or without inflammation occurring in a population in the tropics where pterygium is common. However, a review of our cases of scleritis (unpublished data) revealed that anterior scleritis is not uncommon in Singapore with an incidence of

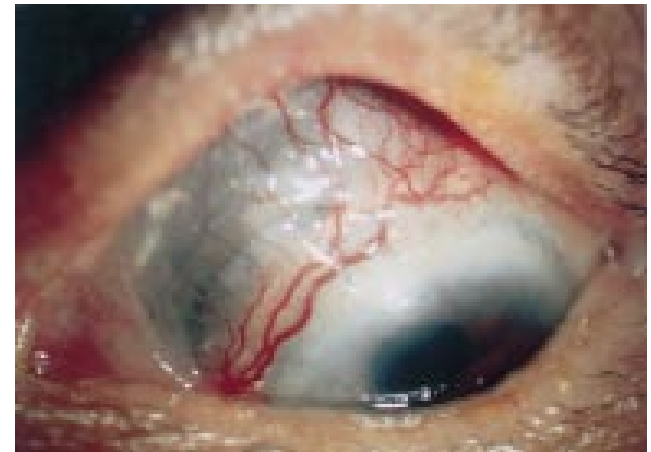

Figure 2 Area of scleral melt in the left eye superonasally with overlying intact conjunctiva.

9.4 cases per year. In contrast, necrotising anterior scleritis is rare, with only four cases having been seen over a 5 year period. The underlying cause in the latter group of patients included Takayasu's disease, syphilis, postECCE wound coagulase negative staphylococcal infection, and one idiopathic case. Although scleral melting after pterygium excision has not classically been described as a form of SINS, which is usually diagnosed after other forms of surgery such as cataract, squint, or encirclage procedures, ${ }^{12}$ this may be because the pathophysiological melting process after pterygium surgery has always previously been linked and ascribed to external adjunctive antiproliferative agents. Certainly, similarities between our cases of pterygium melting and SINS exist; there is a variable latent period between surgery and presentation of melting (which varies from 1 day to 40 years in SINS $^{1}$ ) 
and the area of scleral melt tends to develop adjacent to the surgical wound in both conditions $^{12}$ and may extend to involve the whole anterior segment. These cases may or may not be associated with inflammation. Two of our patients had inflammation which responded to steroid treatment, much as in classical SINS. As in SINS, there can be associated systemic disease with an incidence as high as $40 \%$. $^{1}$ One of our cases had tuberculosis, another had gout. However, their scleritis was not typical of their systemic disease which was of the caseating type in tuberculosis and associated with inflammation without necrosis in gout. One other patient was positive for ANA but she did not develop systemic lupus erythematosus. We do not believe that the scleral melts in these patients were a result of their systemic conditions.

Although the aetiology of SINS is unknown, autoimmunity or hypersensitivity is well accepted as an aetiological factor in its development and derives from the fact that associated clinical or serological markers for connective tissue disorders are present in as many as $62 \%$ of cases. ${ }^{12}$ In addition, immune complexes have been found in and around episcleral vessel walls by immunofluorescence techniques ${ }^{7}$ and systemic immunosuppressive regimes have been found to be successful in the treatment of SINS..$^{12}$ Some of our patients were positive for certain serological connective tissue markers but they did not reveal any history nor develop any signs of underlying connective tissue disease after follow up for 2-3.5 years.

Another accepted hypothesis for the aetiology of SINS is that of localised ischaemia at the surgical site related to disruption of episcleral vasculature such as may occur in squint or encirclage surgery. It is interesting to note that the term "bare sclera" is an apt description of the surgical denudement of episcleral tissue (and vessels) which occurs when pterygium tissue is scrupulously removed, leaving a bare and avascular scleral bed. Excessive punctal cautery promotes this avascular state.

In view of the reported high recurrence rates after bare sclera surgery, ${ }^{6}$ this technique is certainly not very efficacious and, in the light of our report of scleral melting, we suggest that bare sclera surgery for pterygium may not be quite as safe as we had previously thought.

1 O'Donoughue E, Lightman S, Tuft S, et al. Surgically induced necrotising sclerokeratitis (SINS)-precipitating factors and response to treatment. $\mathrm{Br} F$ Ophthalmol 1992;76:17-21.

2 Galanopoulous A, Snibson G, O’Day J. Necrotising anterior scleritis after pterygium surgery. Aust NZ $\mathcal{f}$ Ophthalmol 1994;22:3.

3 Tarr KH, Constable IJ. Late complications of pterygium treatment. Br f Ophthalmol 1980;64:496-505.

4 Mackenzie FD, Hirst LW, Kynaston B, et al. Recurrence rate and complications after beta-irradiation for pterygium. Ophthalmology 1991;98:1776-80.

5 Rubenfeld RS, Pfister RS, Stein RM. Ocular complications of topical mitomycin-C after pterygium surgery. Ophthalmology 1992;99:1647-54.

6 Wong TY, Tan THD. Pterygium surgery: a retrospective analysis of 243 cases in two institutions in Singapore. Paper presented at 14th Singapore-Malaysian Congress in Ophthalmology, 1996.

7 Fong LP, Sainz de LMM, Rice BA, et al. Immunopathology of scleritis. Ophthalmology 1991;98:472-9.

8 Watson PG, Hayreh SS. Scleritis and episcleritis. $\mathrm{Br} F \mathrm{Oph}$ thalmol 1976;60:163-91. Figure 1 Photograph showing area of scleral melt inferonasally in the right eye with uvea exposed and an adjacent sequestrum. A loose eyelash can be seen. Figure 2 Photograph showing area of scleral melt in the left eye superonasally with overlying intact conjunc- 